\title{
Identification of differentially expressed genes in oral squamous cell carcinoma TCA8113 cells
}

\author{
JUN WANG ${ }^{1,2 *}$, LIFENG LI $^{1,2^{*}}$, LINA GAO $^{1}$, CHAO GUAN $^{1}$, KEXIN SU $^{1}$, \\ LINLIN LI ${ }^{1}$, WENPING LUO ${ }^{2,3}$, HONGYING CHEN ${ }^{1}$ and PING JI ${ }^{1,3}$ \\ ${ }^{1}$ Department of Periodontal Surgery, College of Stomatology, Chongqing Medical University; ${ }^{2}$ Chongqing Key Laboratory of \\ Oral Diseases and Biomedical Sciences; ${ }^{3}$ Chongqing Municipal Key Laboratory of \\ Oral Biomedical Engineering of Higher Education, Chongqing 401147, P.R. China
}

Received December 10, 2015; Accepted May 4, 2017

DOI: $10.3892 / \mathrm{ol} .2017 .7108$

\begin{abstract}
Previous studies have demonstrated that cancer cells with increased levels of aldehyde dehydrogenase 'bright' activity $\left(\mathrm{ALDH}^{\mathrm{br}}\right)$ exhibit stem cell properties compared with cells exhibiting decreased ALDH activity $\left(\mathrm{ALDH}^{\mathrm{low}}\right)$. To screen possible biomarkers of cancer stem cells in tongue squamous cell carcinoma, $\mathrm{ALDH}^{\text {br }}$ and $\mathrm{ALDH}^{\text {low }}$ cells were isolated from the tongue squamous cell carcinoma TCA8113 cell line, and suppression subtractive hybridization was performed to identify differentially expressed genes in the two subpopulations. A total of 240 positive clones were randomly selected for sequencing and were functionally characterized using bioinformatical tools. The results of the present study identified the differential expression of 104 clones, 62 of which corresponded to known genes and 42 of which corresponded to unknown genes. Cluster analysis revealed that the known genes were involved in the regulation of the cell cycle and cell differentiation. In addition, analysis of 10 signaling pathways revealed that genes were markedly altered in the $\mathrm{ALDH}^{\mathrm{br}}$ cell subpopulation. Additional study is required to identify the function that these genes serve in the biomolecular regulatory mechanisms of cancer stem cells and to assist in explaining the biological behavior of oral squamous cell carcinoma.
\end{abstract}

\section{Introduction}

Oral squamous cell carcinoma (OSCC) is the most common type of head and neck squamous cell carcinoma (HNSCC), and is among the 10 most prevalent cancer types worldwide $(1,2)$.

Correspondence to: Dr Ping Ji, Department of Periodontal Surgery, College of Stomatology Chongqing Medical University, 426 Songshibei Road, Chongqing 401147, P.R. China

E-mail: jiping1962@hotmail.com

*Contributed equally

Key words: oral squamous cell carcinoma, tumor stem cell, aldehyde dehydrogenase, genes, suppression subtractive hybridization
In spite of improvements in the diagnosis and prognosis of OSCC, long-term survival rates have not improved in the past decade (3). To develop effective therapies, an improved understanding of the biological features and underlying molecular mechanisms of OSCC are required.

In previous studies, it has been suggested that the cancer stem cell (CSC) hypothesis may be applied to a number of types of cancer $(4,5)$. According to the hypothesis, a tumor may be viewed as an aberrant organ initiated by a subpopulation of cells, termed CSCs, which exhibit self-renewing capacities and are responsible for tumor maintenance and metastasis (6). The hypothesis provides a novel insight into the understanding of tumorigenesis and since then, the isolation and identification of CSCs have been studied in depth. Previous studies have supported the validity of this hypothesis in a number of malignant diseases, including breast cancer, brain tumor, colon cancer, melanomas and prostate cancer (7-11). In addition, the existence of CSCs has been identified in HNSCC and has been associated with the expression of aldehyde dehydrogenase (ALDH) (12). Cells with increased ADLH 'bright' activity $\left(\mathrm{ALDH}^{\mathrm{br}}\right)$ exhibit CSC-associated properties, including radio-resistance and the ability to produce tumors with a limited number of cells, which is in contrast to cells with decreased ALDH activity $\left(\mathrm{ALDH}^{\mathrm{low}}\right)(13,14)$. However, the gene expression profile of the two cell subpopulations remains unknown, which is required to understand the underlying molecular mechanisms of CSCs in HNSCC.

In the present study, $\mathrm{ALDH}^{\mathrm{br}}$ and $\mathrm{ALDH}^{\text {low }}$ cells were isolated from the OSCC TCA8113 cell line and suppression subtractive hybridization ( $\mathrm{SSH}$ ) was subsequently performed to identify differentially expressed genes in the two subpopulations. Known and unknown differentially expressed genes were identified in subtracted clones, and the known genes were functionally characterized using bioinformatical tools. The results of the present study suggested that the identified genes may be biomarkers for the identification of CSCs in OSCC.

\section{Materials and methods}

Cells and cell culture. The tongue squamous cell carcinoma TCA8113 cell line was obtained from the West China College of Stomatology of Sichuan University (Sichuan, China). Cells 
were maintained in RPMI 1640 medium (Invitrogen; Thermo Fisher Scientific, Inc., Waltham, MA, USA), supplemented with $10 \%$ fetal bovine serum (Invitrogen; Thermo Fisher Scientific, Inc.), $1 \%$ glutamine and $1 \%$ penicillin-streptomycin at $37^{\circ} \mathrm{C}$ in a humidified atmosphere containing $5 \% \mathrm{CO}_{2}$.

ALDH assay and cell sorting. An Aldefluor kit (Stemcell Technologies, Inc., Vancouver, BC, Canada) was used to determine ALDH activity in TCA8113 cells, according to the manufacturer's protocol. Cells were suspended in Aldefluor assay buffer, which contained an activated Aldefluor substrate (BAAA, $1 \mu \mathrm{mol} / 1 \times 10^{6}$ cells), as recommended by the manufacturer. As a negative control for all samples, an aliquot of 'Aldefluor-exposed' cells $\left(1 \times 10^{8}\right.$ cells) was transfused into the control tube, which contained $5 \mu l$ diethylaminobenzaldehyde (DEAB), a specific ALDH inhibitor. Following incubation at $37^{\circ} \mathrm{C}$ for $40 \mathrm{~min}$, the cells were centrifuged at $250 \mathrm{x}$ g for $5 \mathrm{~min}$ and the supernatant was removed. Subsequently, the cell pellets were resuspended in $0.5 \mathrm{ml}$ ice-cold Aldefluor Assay Buffer, and flow cytometric analysis was performed using FACSAria (BD Biosciences, Franklin Lakes, NJ, USA). Aldefluor staining was determined using a green fluorescence channel. Samples treated with DEAB were used as controls and set the threshold that defined the $\mathrm{ALDH}^{\mathrm{br}}$ region.

Tumorsphere formation. Since CSCs typically form tumorspheres and non-CSCs die in serum-free medium $(15,16)$, tumorsphere formation in $\mathrm{ALDH}^{\mathrm{br}}$ and $\mathrm{ALDH}^{\text {low }}$ cells was investigated in the present study. Cells were plated at a low density $(1,000$ cells/ml in RPMI1 640 serum-free medium, supplemented with human recombinant epidermal growth factor (20 ng/ml; PeproTech, Inc., Rocky Hill, NJ, USA), basic fibroblast growth factor (20 ng/ml; PeproTech, Inc.) and B27 serum-free supplements ( $20 \mu \mathrm{l} / \mathrm{ml}$; Invitrogen; Thermo Fisher Scientific, Inc.). The formation of tumorspheres was observed daily using an inverted phase contrast microscope (magnification, $\mathrm{x} 100)$.

Preparation of total RNA. Total RNA was isolated from $\mathrm{ALDH}^{\mathrm{br}}$ and $\mathrm{ALDH}^{\text {low }}$ cells using TRIzol reagent (Invitrogen; Thermo Fisher Scientific, Inc.), according to the manufacturer's protocol. Total RNA was quantified using a Unico UV-2000 spectrophotometer (Unico Technologies Co., Ltd., Jiangsu, China). The $\mathrm{A}_{260} / \mathrm{A}_{280}$ ratio was between 1.8 and 2.0. Total RNA $(\sim 1 \mu \mathrm{g})$ was separated on denaturing agarose $(1.2 \%$ gel $)$ to confirm integrity.

cDNA synthesis. cDNA was synthesized using the SMART ${ }^{\mathrm{TM}}$ cDNA Synthesis kit (Clontech Laboratories, Inc., Mountain View, CA, USA) according to the manufacturer's protocol. Total RNA $(1 \mu \mathrm{g})$ was reverse transcribed $\left(42^{\circ} \mathrm{C}, 1.5 \mathrm{~h}\right)$ in a $10-\mu 1$ reaction mixture containing PowerScript ${ }^{\mathrm{TM}}$ reverse-transcriptase. Sterile $\mathrm{H}_{2} \mathrm{O}(24.2 \mu \mathrm{l}), 5 \mathrm{X}$ Second-Strand Buffer $(8.0 \mu \mathrm{l})$, dNTP mix $(10 \mathrm{mM} ; 0.8 \mu \mathrm{l})$ and 20X Second-Strand Enzyme Cocktail $(2.0 \mu \mathrm{l})$ were added to the $10 \mu \mathrm{l}$ first-strand synthesis reaction tubes and incubated at $16^{\circ} \mathrm{C}$ for $2 \mathrm{~h}$ in water. T4 DNA polymerase (Clontech Laboratories, Inc.) $2 \mu 1$ was then added followed by incubation at $16^{\circ} \mathrm{C}$ for $30 \mathrm{~min}$ in a water bath. Subsequently, $4 \mu 1$ of 20X EDTA/glycogen mix was added to terminate second-strand synthesis, followed by addition of $100 \mu \mathrm{l}$ of phenol:chloroform:isoamyl alcohol (25:24:1). Centrifugation was then performed at 2,191.28 $\mathrm{x}$ g for $10 \mathrm{~min}$ at room temperature. The top aqueous layer was collected and placed in a fresh $0.5-\mathrm{ml}$ microcentrifuge tube. The inter and lower phases were discarded and disposed appropriately. Next, $100 \mu 1$ of chloroform:isoamyl alcohol (24:1) was added, followed by addition of $40 \mu \mathrm{l}$ of $4 \mathrm{M} \mathrm{NH}_{4} \mathrm{OAc}$ and $300 \mu \mathrm{l}$ of 95\% ethanol. Subsequently, centrifugation was performed at $2,191.28 \mathrm{x}$ g for $20 \mathrm{~min}$ at room temperature, and the supernatant was collected. The pellet was overlayed with $500 \mu \mathrm{l}$ of $80 \%$ ethanol, and then centrifuged at 2,191.28 $\mathrm{x}$ g for $10 \mathrm{~min}$ at room temperature. The supernatant was removed and the pellet was air-dried for $\sim 10 \mathrm{~min}$ to evaporate residual ethanol. Precipitate was dissolved in $50 \mu \mathrm{l}$ of sterile $\mathrm{H}_{2} \mathrm{O}$, and $6 \mu \mathrm{l}$ was transferred to a fresh microcentrifuge tube. This sample was stored at $-20^{\circ} \mathrm{C}$ until after $R s a$ I digestion (for agarose gel electrophoresis) to estimate yield and size range of ds cDNA products synthesized.

SSH. Synthesized two-target cDNA was used for SSH, performed with the PCR-select ${ }^{\mathrm{TM}}$ cDNA Subtraction kit (Clontech Laboratories, Inc.), according to the manufacturer's protocol. cDNA from ALDH ${ }^{\text {br }}$ and ALDH ${ }^{\text {low }}$ cells was used as the 'tester' and 'driver', respectively, in the forward subtraction and vice versa for the reverse subtraction. For each subtraction, the 'tester' was ligated to adaptor 1 and adaptor $2 \mathrm{R}$ in separate ligation reactions, whereas the 'driver' was not ligated to adaptors. Following ligation, two samples were subjected to hybridization. For the first hybridization, an excess of 'driver' cDNA was added to each adaptor-ligated 'tester' cDNA in the hybridization buffer, heat-denatured $\left(98^{\circ} \mathrm{C}, 1.5 \mathrm{~min}\right)$ and subsequently annealed $\left(68^{\circ} \mathrm{C}, 8 \mathrm{~h}\right)$. The two samples from the first hybridization were mixed and fresh denatured 'driver' cDNA was added and annealed at $68^{\circ} \mathrm{C}$ overnight. Following the second hybridization, the sample was diluted in $200 \mu \mathrm{l}$ dilution buffer and incubated at $68^{\circ} \mathrm{C}$ for $7 \mathrm{~min}$ in a thermal cycler. Subsequently, PCR was performed using the subtracted cDNAs to amplify the desired differentially expressed sequences. The first-round PCR was performed using PCR primer 1 (5'-CTAATACGACTCACTATAGGGC-3') and the cycling parameters were $72^{\circ} \mathrm{C}$ for $10 \mathrm{~min}$ and $95^{\circ} \mathrm{C}$ for $2 \mathrm{~min}$, followed by 25 cycles of $94^{\circ} \mathrm{C}$ for $30 \mathrm{sec}, 62^{\circ} \mathrm{C}$ for $45 \mathrm{sec}, 72^{\circ} \mathrm{C}$ for $1 \mathrm{~min}$ and $72^{\circ} \mathrm{C}$ for $6 \mathrm{~min}$. The second-round PCR reaction was performed using nested primer 1 (5'-TCGAGCGGCCGC CCGGGCAGGT-3') and nested primer 2R (5'-AGCGTGGTC GCGGCCGAGGT-3'), and the cycling parameters were $95^{\circ} \mathrm{C}$ for $2 \mathrm{~min}$, followed by 29 cycles of $94^{\circ} \mathrm{C}$ for $30 \mathrm{sec}, 65^{\circ} \mathrm{C}$ for $45 \mathrm{sec}, 72^{\circ} \mathrm{C}$ for $1 \mathrm{~min}$ and $72^{\circ} \mathrm{C}$ for $6 \mathrm{~min}$.

Cloning of SSH-PCR products. The purified secondary SSH-PCR products were cloned into PMD-18T vector (Takara Bio, Inc., Otsu, Japan) and the ligated products were transformed into E. coli DH5 a competent cells. Transformed colonies were selected on Luria-Bertani (LB) agar medium (MP Biomedicals, Santa Ana, CA, USA) containing ampicillin (100 mg/l) at $37^{\circ} \mathrm{C}$ and $\sim 1,000$ positive colonies were obtained, which represented subtraction libraries enriched with differentially expressed genes. A total of 240 positive colonies were selected randomly. A single clone was inoculated in $2 \mathrm{ml}$ LB-ampicillin $(100 \mathrm{mg} / \mathrm{l})$ and incubated overnight at $37^{\circ} \mathrm{C}$ with gentle agitation at $44.72 \mathrm{x} \mathrm{g}$. 
A

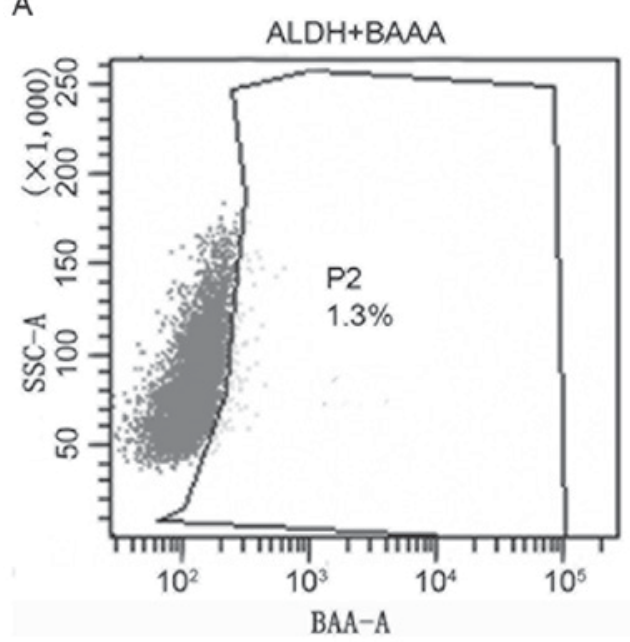

B

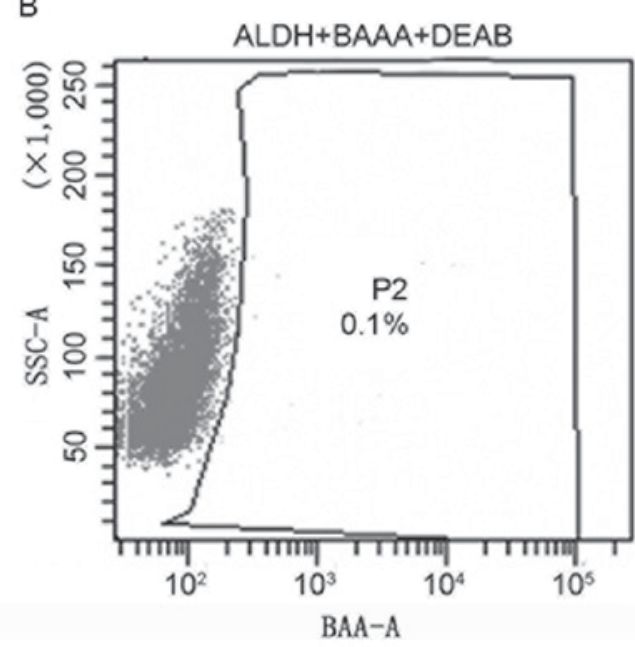

Figure 1. Isolation of ALDH ${ }^{\text {br }}$ cells in tongue squamous cell carcinoma TCA8113 cells. (A) Cells incubated with Aldefluor substrate (BAAA) and subsequent fluorescence-activated cell sorting was used to identify cells exhibiting increased ALDH activity (P2 region, 1.3\%). (B) With the addition of DEAB, a specific inhibitor of $\mathrm{ALDH}$, the proportion of sorted $\mathrm{ALDH}^{\text {br }}$ cells was markedly decreased (P2 region, $0.1 \%$ ). ALDH, aldehyde dehydrogenase; DEAB, diethylaminobenzaldehyde; SSC-A, side scatter area.

PCR amplification of cDNA inserts. To assess the size of inserts, colony PCR was performed in a 50- $\mu 1$ reaction system containing 12.5 $\mu \mathrm{l}$ 10X buffer (Takara Bio, Inc.), $1 \mu 110 \mathrm{mM}$ dNTP (Shanghai CPG Biotechnology Co., Ltd., Shanghai, China), $5 \mu \mathrm{lgCl}_{2}$ (Takara Bio, Inc.), $1 \mu 150 \mathrm{pM} / \mu 1$ Nested primer 1 (Clontech Laboratories, Inc.), $1 \mu 150 \mathrm{pM} / \mu 12 \mathrm{R}$ primer (Clontech Laboratories, Inc.), and 2.5 U Taq DNA polymerase (Takara Bio, Inc.). The PCR parameters were: $95^{\circ} \mathrm{C}$ for $2 \mathrm{~min}$, followed by 35 cycles of $95^{\circ} \mathrm{C}$ for $30 \mathrm{sec}, 62^{\circ} \mathrm{C}$ for $45 \mathrm{sec}$ and $72^{\circ} \mathrm{C}$ for $1 \mathrm{~min}$. Colony PCR products $(2 \mu \mathrm{l})$ were separated using agarose $(1.2 \%$ gel) to identify the presence and the size of the inserts prior to sequencing. The controls for this protocol included the unsubtracted tester control for the forward subtraction, the unsubtracted tester control for the reverse subtraction and the unsubtracted tester control for the control skeletal muscle tester cDNA [made from the Control Poly $\mathrm{A}^{+}$RNA (from human skeletal muscle) provided with the kit (the SMART ${ }^{\mathrm{TM}}$ cDNA Synthesis kit (Clontech Laboratories, Inc.)]. It serves as control driver cDNA subtraction. All protocols were repeated 3 times.

Expressed sequenced tag (EST) sequencing and bioinformatical analysis. The selected positive clones were sequenced at the Beijing Genomics Institute (Beijing, China) and the sequences were edited to remove the adaptor-primer and vector DNA sequences. ESTs were compared with non-redundant public databases using the Basic Local Alignment Search Tool (BLAST) (blast.ncbi.nlm.nih.gov/Blast.cgi) nucleotide to retrieve data from GenBank (www.ncbi.nlm.nih. gov/nucleotide) and BLASTX (blast.ncbi.nlm.nih.gov/Blast. cgi?PROGRAM=blastx\&PAGE_TYPE=BlastSearch\&LINK_ LOC=blasthome) algorithms of the National Center for Biotechnology Information (NCBI; blast.ncbi.nlm.nih.gov/ Blast.cgi). ESTs with $\mathrm{E}<0.01$ were deemed to exhibit significant homology. Homologies $>50$ nucleotides that exhibited $>90 \%$ identity to sequences in the database were considered to have significant homologies, as previously described (17). The physiological functions of these ESTs were classified according to
Gene Ontology (www.geneontology.org). Pathway analysis was performed using the Gene Set Analysis Toolkit V2 online system (www.webgestalt.org/option.php).

\section{Results}

Isolation of $A L D H^{b r}$ cells in tongue squamous cell carcinoma TCA8113 cells. Using the ALDEFLUOR assay and fluorescence-activated cell sorting analysis, the ALDH enzymatic activity in the tongue squamous cell carcinoma TCA8113 cell line was identified to be heterogeneous. As presented in Fig. 1, only a limited proportion (1.3\%) of the cells displayed increased ALDH activity (ALDH ${ }^{\text {br }}$; Fig. 1A), whereas the remaining cells expressed decreased levels of ALDH activity $\left(A L D H^{\text {low }}\right)$. DEAB, the specific inhibitor of ALDH, resulted in a decreased proportion of sorted $\mathrm{ALDH}^{\mathrm{br}}$ cells (0.1\%; Fig. 1B), suggesting the effective isolation of $\mathrm{ALDH}^{\mathrm{br}}$ cells. The results of the present study revealed that cancer stem cells with $\mathrm{ALDH}^{\mathrm{br}}$ were successfully isolated. Subpopulation cells were selected for additional analysis.

ALDH ${ }^{b r}$ cells form spheres. CSCs may be effectively enriched in serum-free medium (18-20). The majority of cells die in serum-free medium due to a lack of nutritive materials; however, CSCs may survive, proliferate and form three-dimensional spheres. In the present study, $\mathrm{ALDH}^{\mathrm{br}}$ cells maintained in serum-free medium proliferated and formed spheres within 5 days, whereas ALDH $^{\text {low }}$ cells, maintained in the same medium, did not form spheres and were apoptotic (Fig. 2). The results of the present study indicated that the isolated $\mathrm{ALDH}^{\mathrm{br}}$ cells exhibited typical CSC features.

Constructing the SSH library. Using cDNA from ALDH ${ }^{\text {br }}$ cells as 'testers' and that of ALDH ${ }^{\text {low }}$ cells as 'drivers' and vice versa, PCR-selected cDNA subtraction for forward and reverse libraries, respectively, was performed. Following subtraction, a pool of putative differentially expressed cDNA fragments was obtained. The cDNA fragments ranged between $200 \mathrm{bp}$ 
A

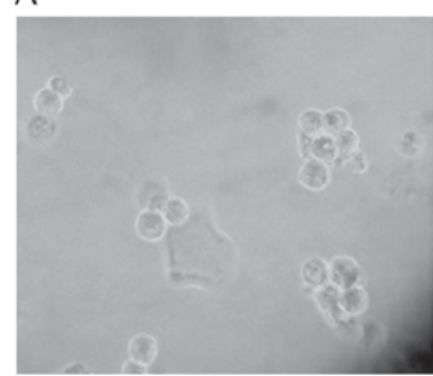

B

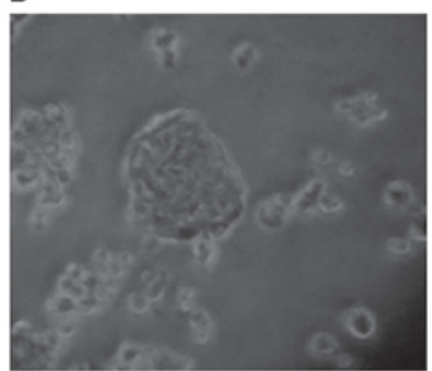

C

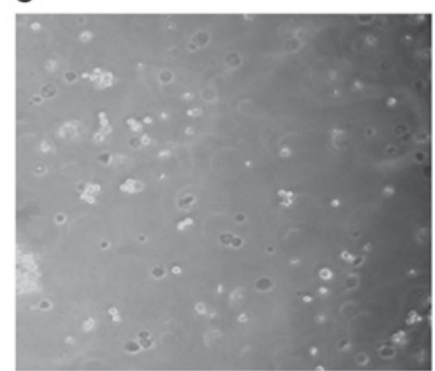

Figure 2. Sphere formation of cells exhibiting increased ALDH activity. Isolated cells exhibiting increased and decreased ALDH activity were maintained in serum-free RPMI 1640 medium. Cells were subsequently inspected using an inverted phase contrast microscope (magnification, x100) at a variety of culture times. Cells exhibiting increased ALDH activity formed spheres on (A) day 5 and (B) day 10; (C) whereas cells exhibiting decreased activity of ALDH died on day 5 . ALDH, aldehyde dehydrogenase.

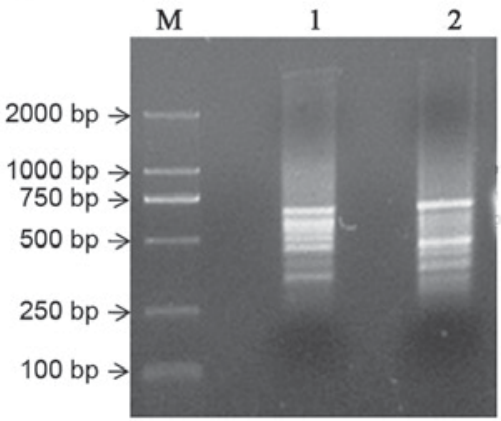

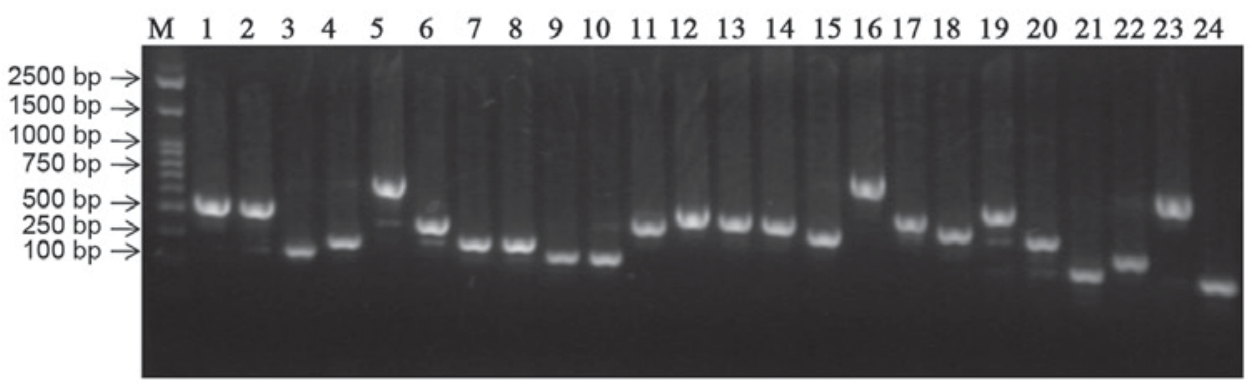

Figure 3. Construction of the suppression substrate hybridization library. (A) Products of PCR-select cDNA subtraction. (B) cDNA fragments of distinct lengths from white clones, amplified using PCR. PCR, polymerase chain reaction; M, DNA marker; 1, forward subtraction products; 2 , reverse subtraction products.

and $1 \mathrm{~kb}$, with the majority distributed between 400 and $600 \mathrm{bp}$ (Fig. 3A). Subtracted amplicons were ligated into the PMD-18T plasmid vector and transformed into $E$. coli $\mathrm{DH} 5 \alpha$ competent cells. In total, 240 white colonies were randomly selected and 48 of these clones were subjected to colony PCR, using nested primers. All the recombinants determined revealed amplicons ranging between 200 and 800 bp (Fig. 3B).

Identification of differentially expressed ESTs. All 240 clones were selected and sequenced. Sequences were not obtained for 14 clones and those were omitted from the present study. Comparison of the unique sequences obtained from each library against the GenBank databases identified 104 unique clones, 62 of which corresponded to known genes and 42 of which were unknown genes, while the remaining 122 clones were redundant. Of the known genes, 28 and 34 genes were upregulated and downregulated in $\mathrm{ALDH}^{\mathrm{br}}$ cells, respectively (Tables I and II). The unknown clones were divided into two groups in the NCBI databases, 28 represented human genomic sequences and 14 were present in the human EST database.

Functional classification of differentially expressed ESTs. On the basis of the functional annotation using Gene Ontology (GO) software, 62 differentially expressed genes were grouped into a number of categories (Fig. 4). In the GO category of biological processes, the highly enriched categories included those associated with metabolic processes ( 28 genes), biological regulation (21 genes) and developmental processes (16 genes).
The molecular functions with those highly enriched genes were associated with protein binding (32 genes) and cellular components in the nucleus ( 24 genes).

Pathway analysis of differentially expressed ESTs. Signal pathway analysis was performed based on the Wikipathways database and the Pathway Commons database, using the Gene Set Analysis Toolkit V2. The 10 signaling pathways with the most marked alterations in each database are presented in Tables III and IV, and included the transforming growth factor (TGF-) $\beta$ signaling pathway, the Notch signaling pathway and the c-kit pathway. Typically, $\sim 10$ genes were enriched in these pathways and each gene may participate in a number of pathways.

\section{Discussion}

CSCs refer to a subset of tumor cells that exhibit the capability to self-renew and generate diverse cells that comprise the tumor $(4,21)$, and have been termed CSCs to reflect the 'stem-like' properties and the ability to sustain tumorigenesis. CSCs share important properties with healthy tissue stem cells, including the capacity for self-renewal and differentiation. An implication of the CSC hypothesis is that cancer cells are hierarchically arranged with CSCs located at the apex of the hierarchy (22). CSCs are the only cells that may maintain tumor viability indefinitely. The remaining cells, although actively proliferating and comprising the majority of the tumor, are 


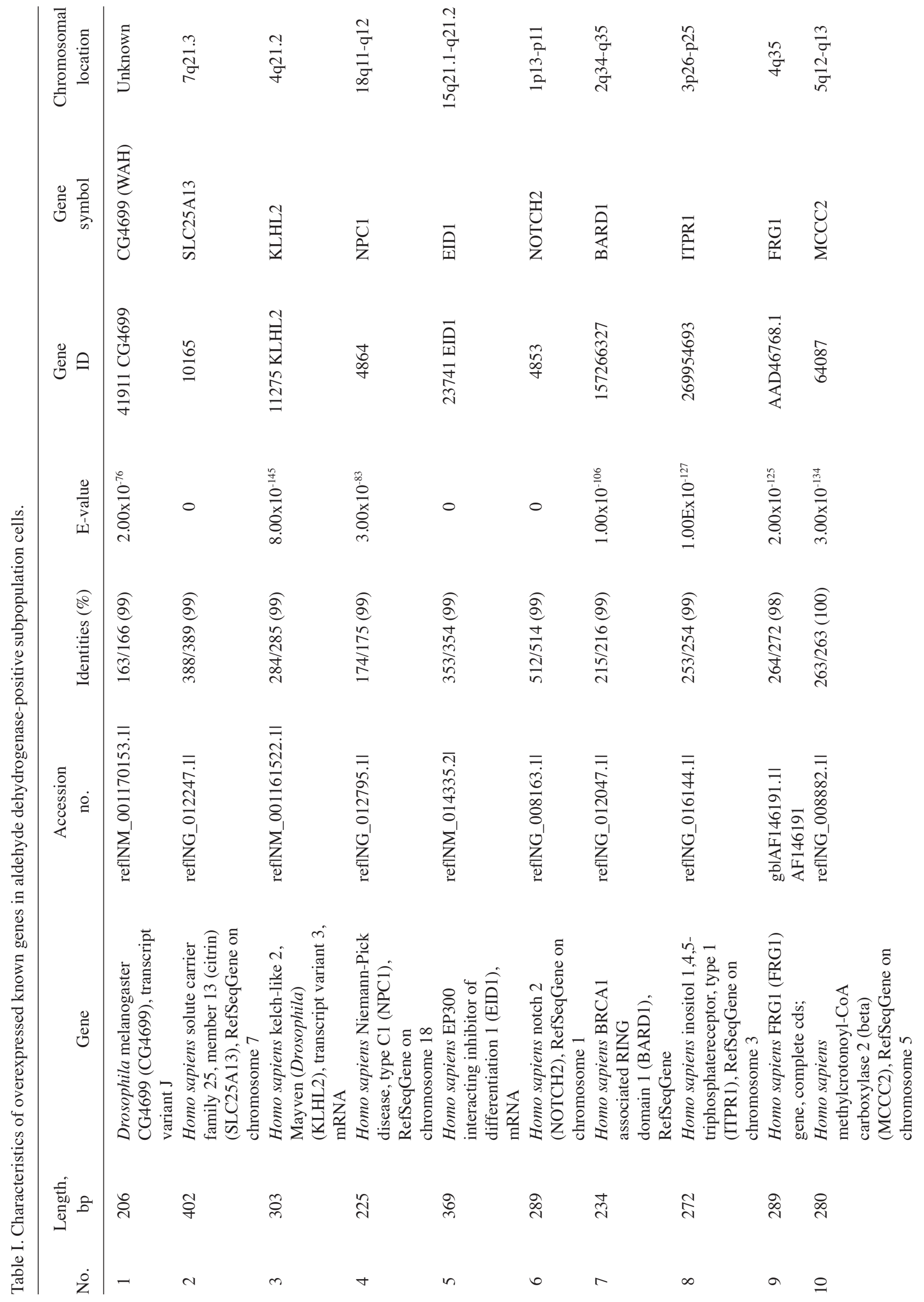




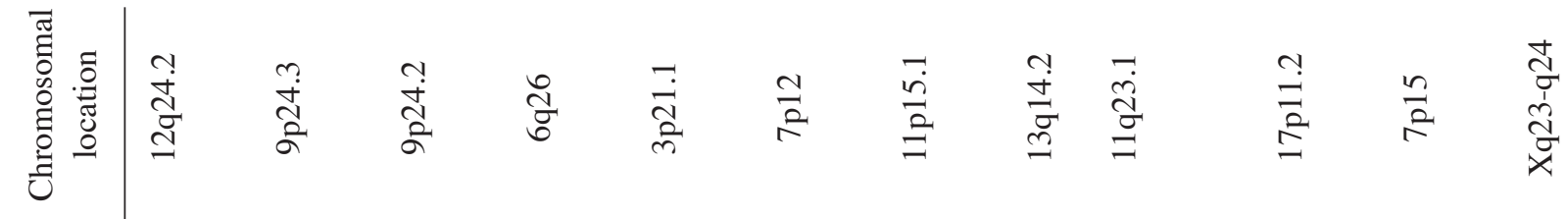

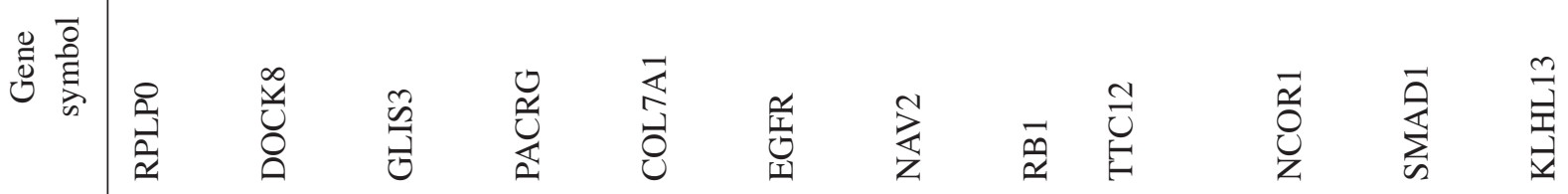

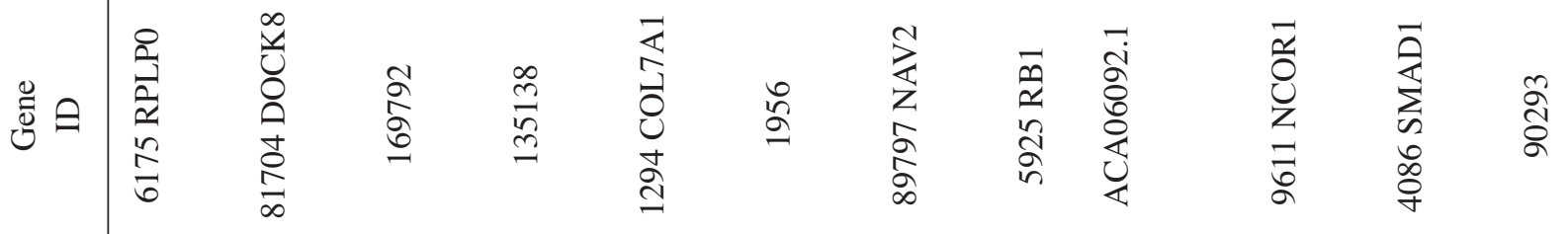

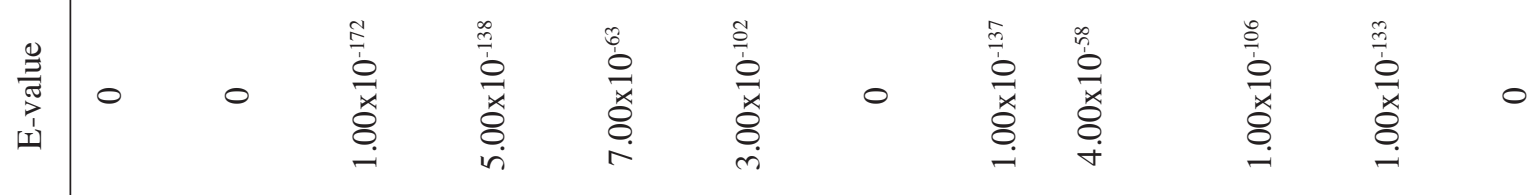

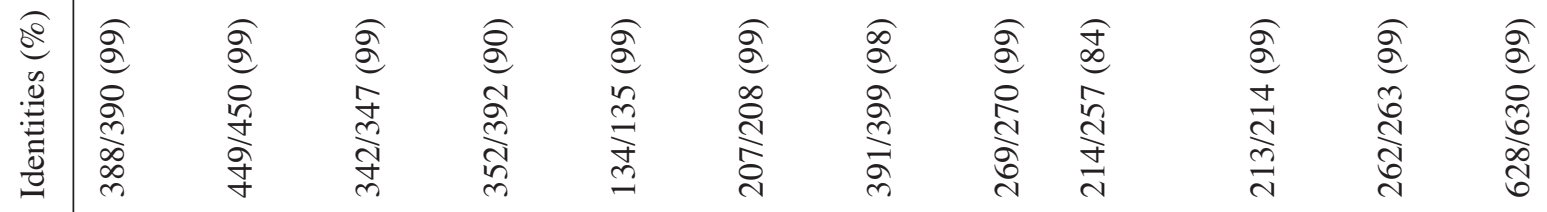

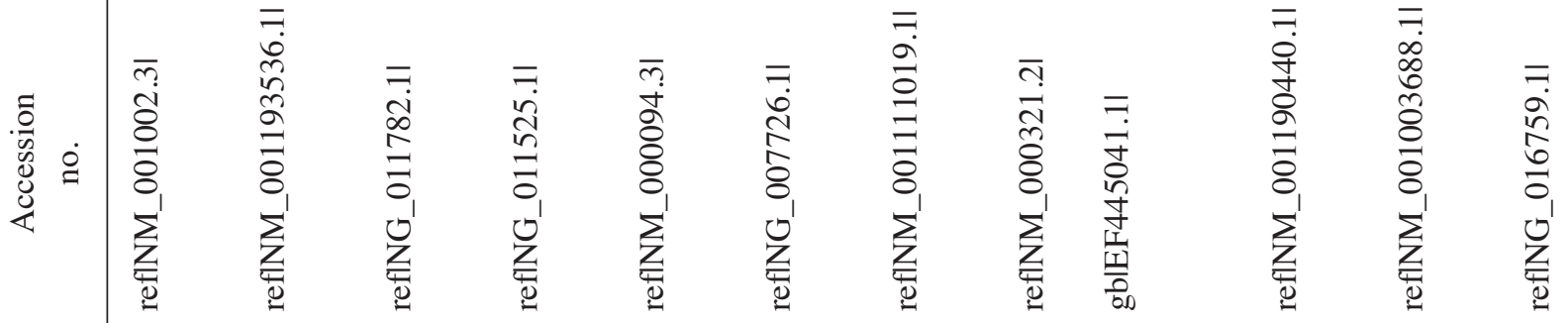

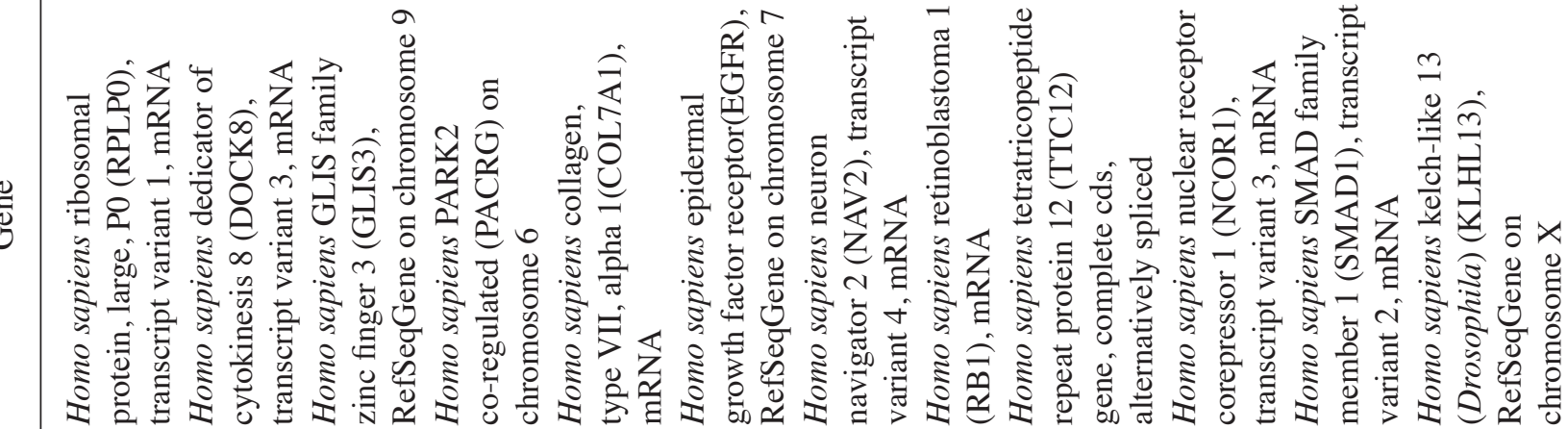

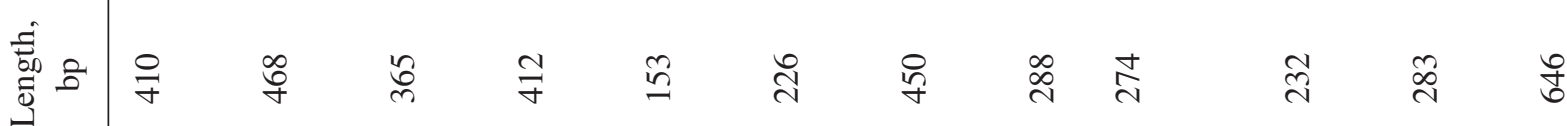

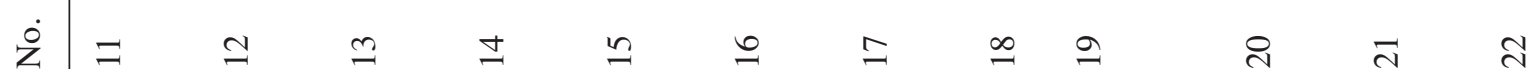




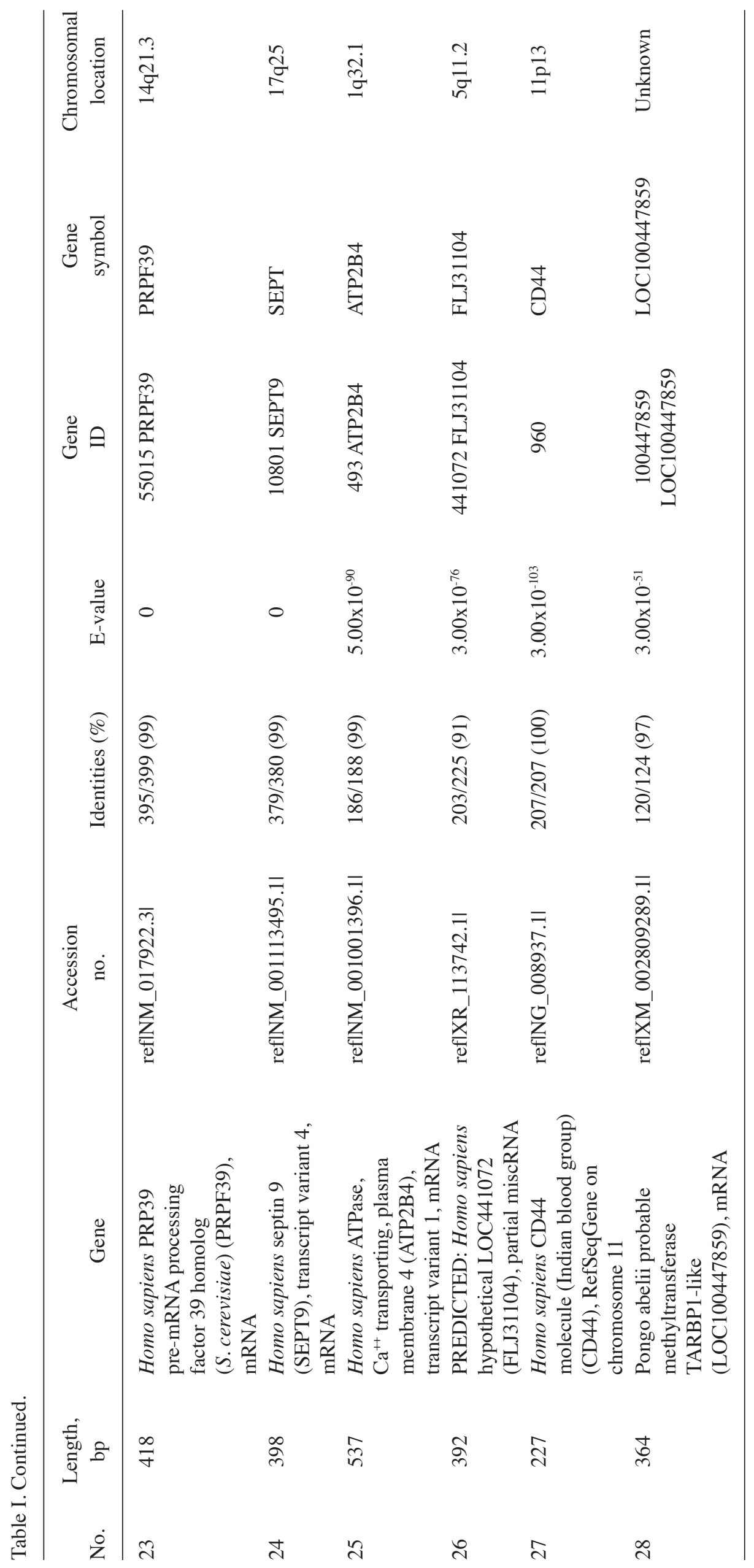




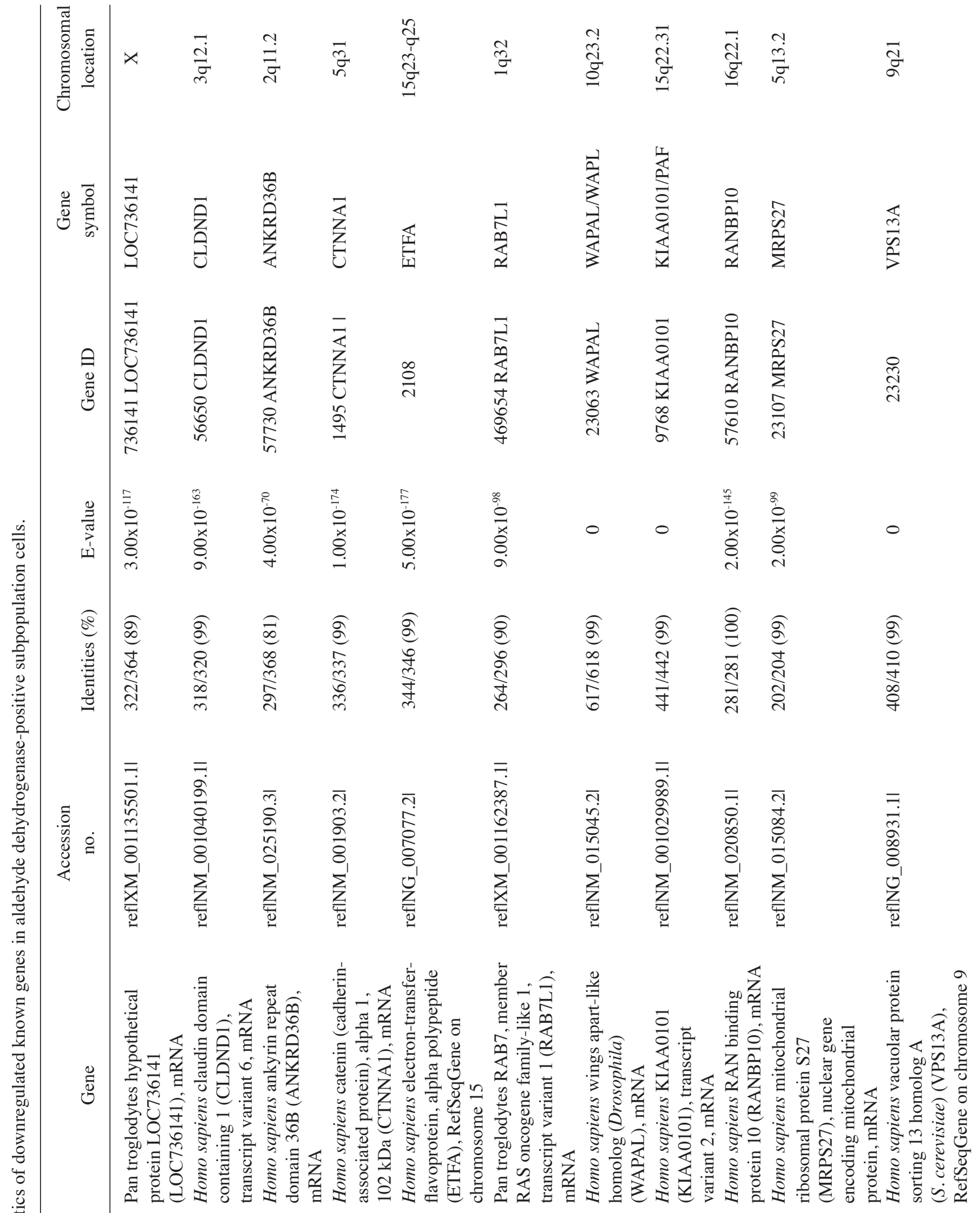

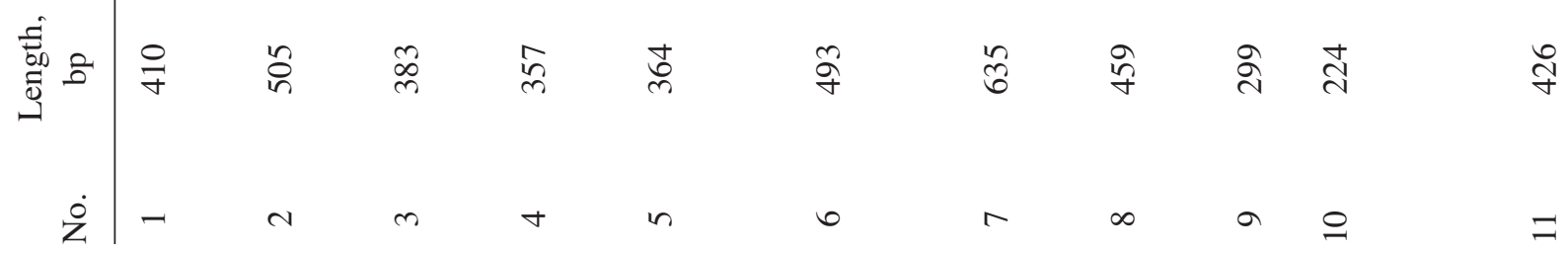




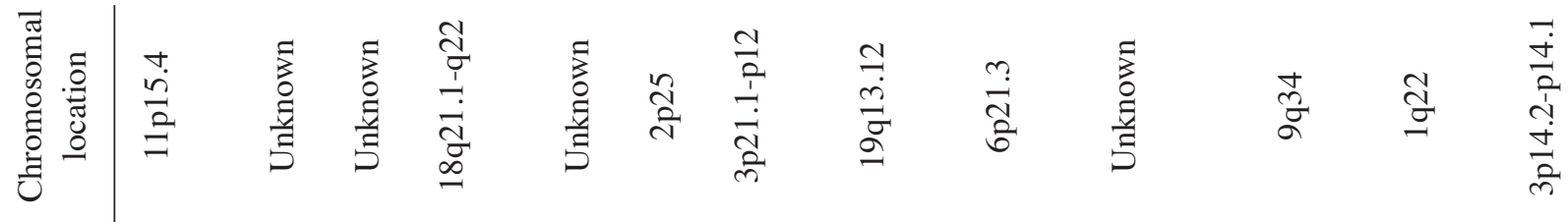

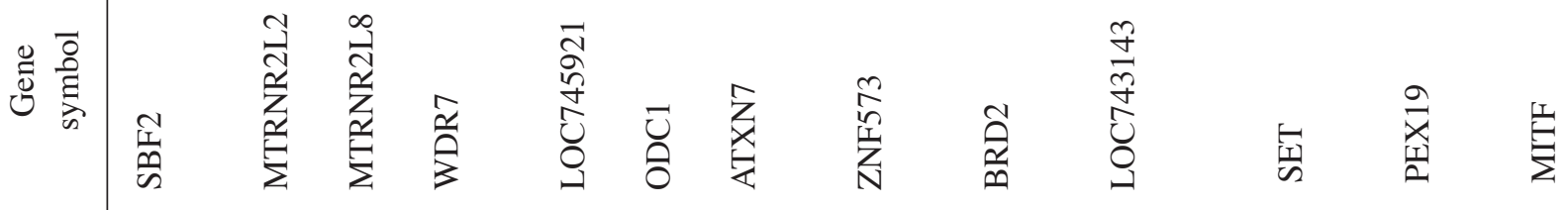

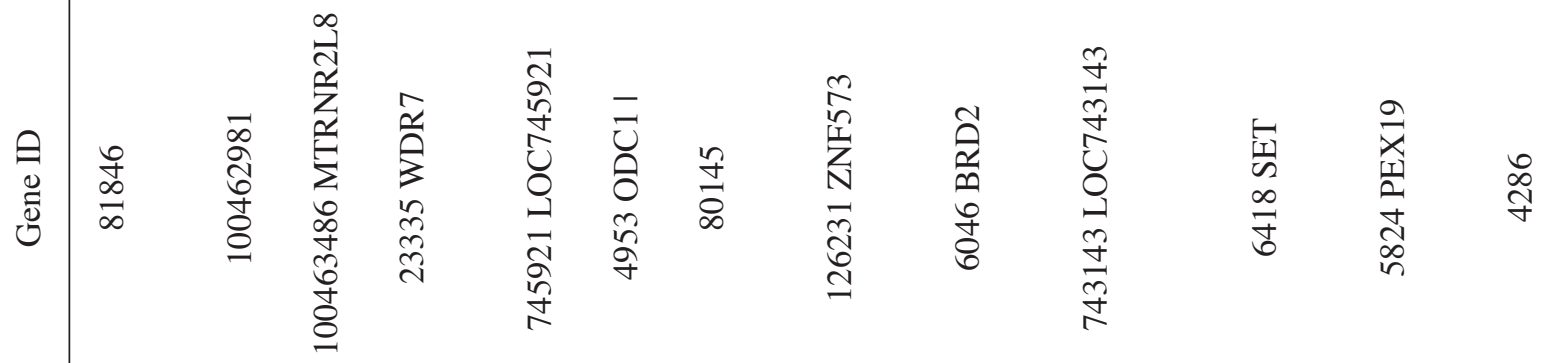

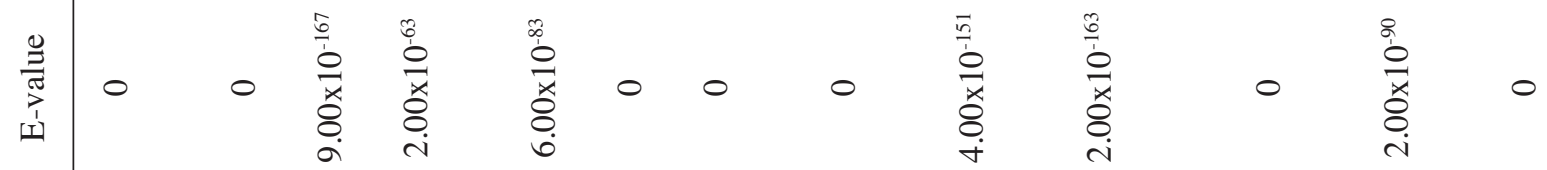

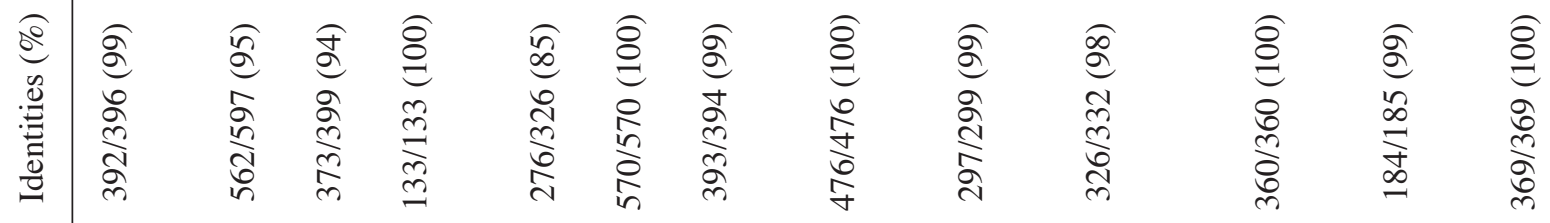

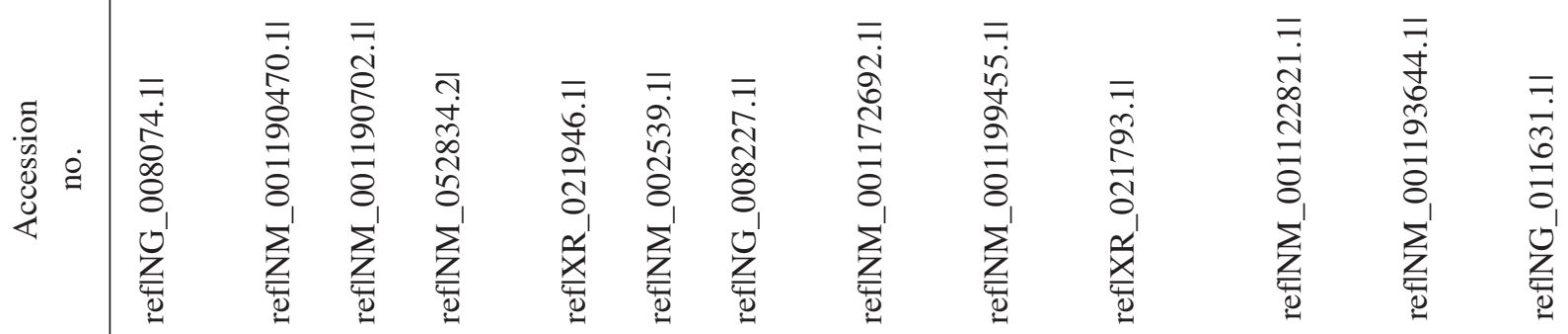

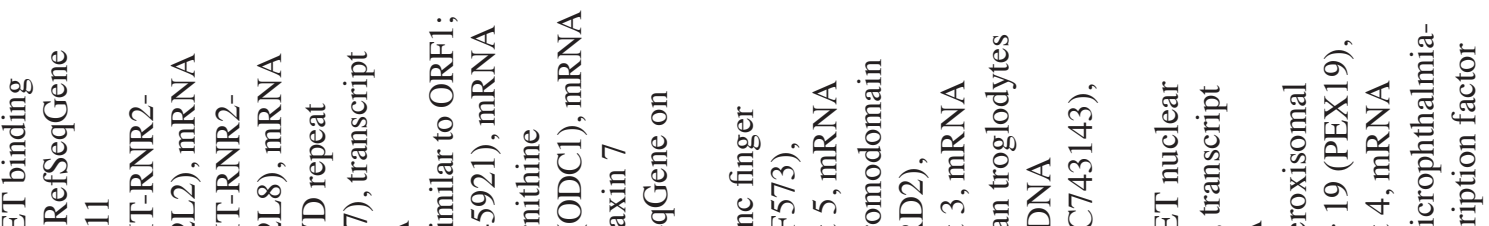

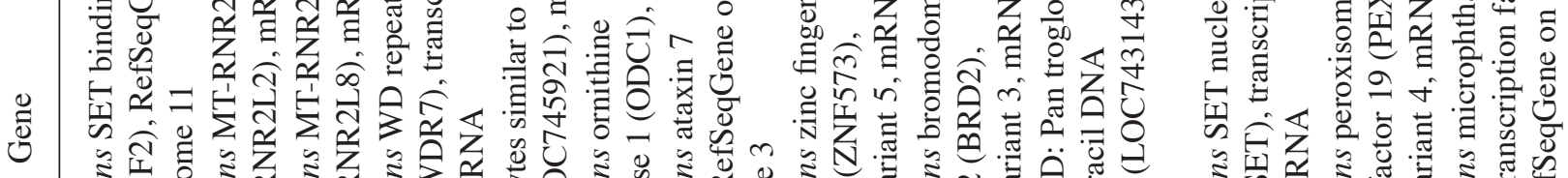

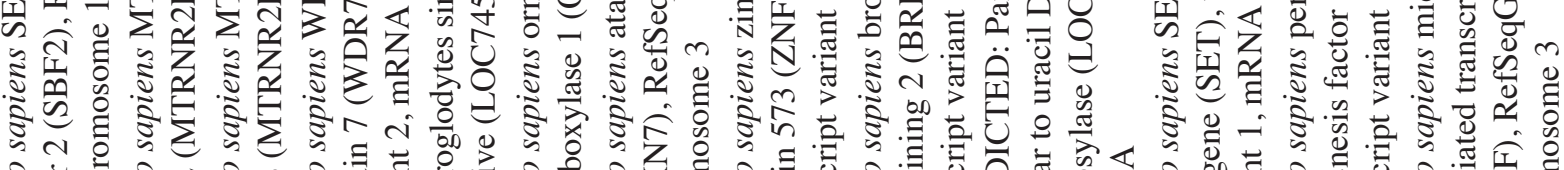

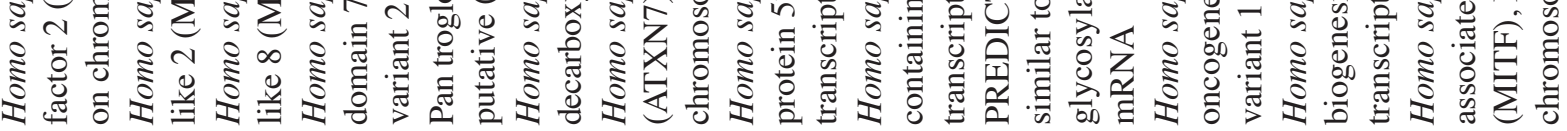

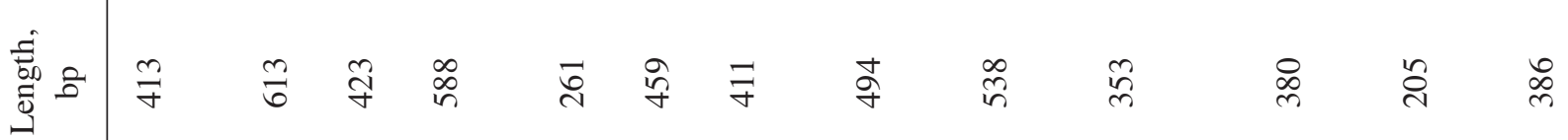

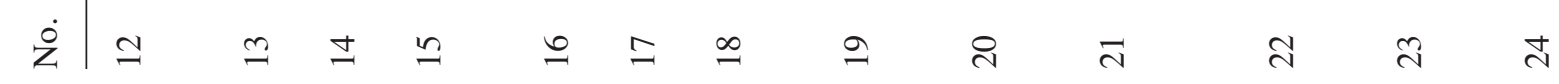




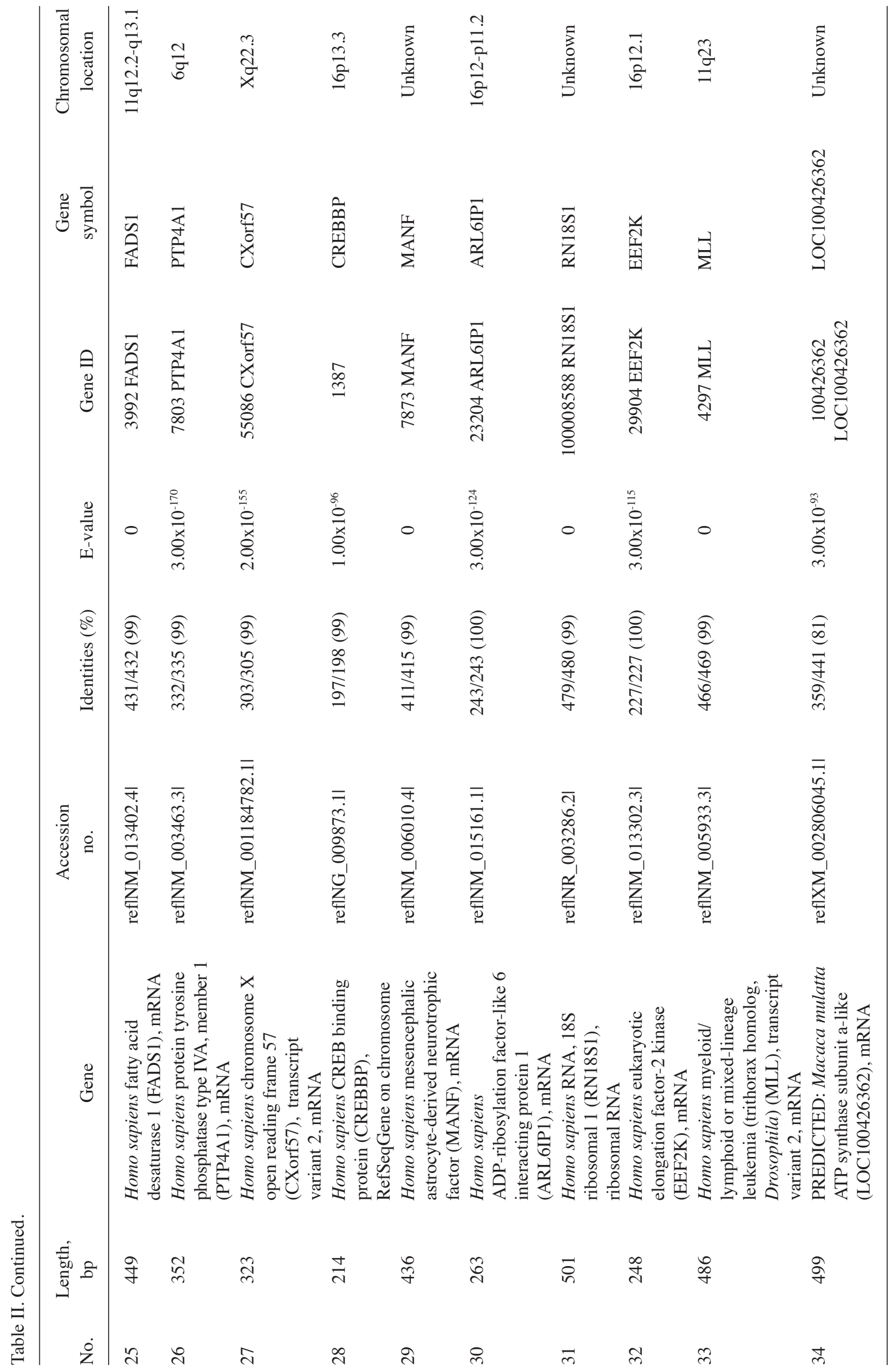


A

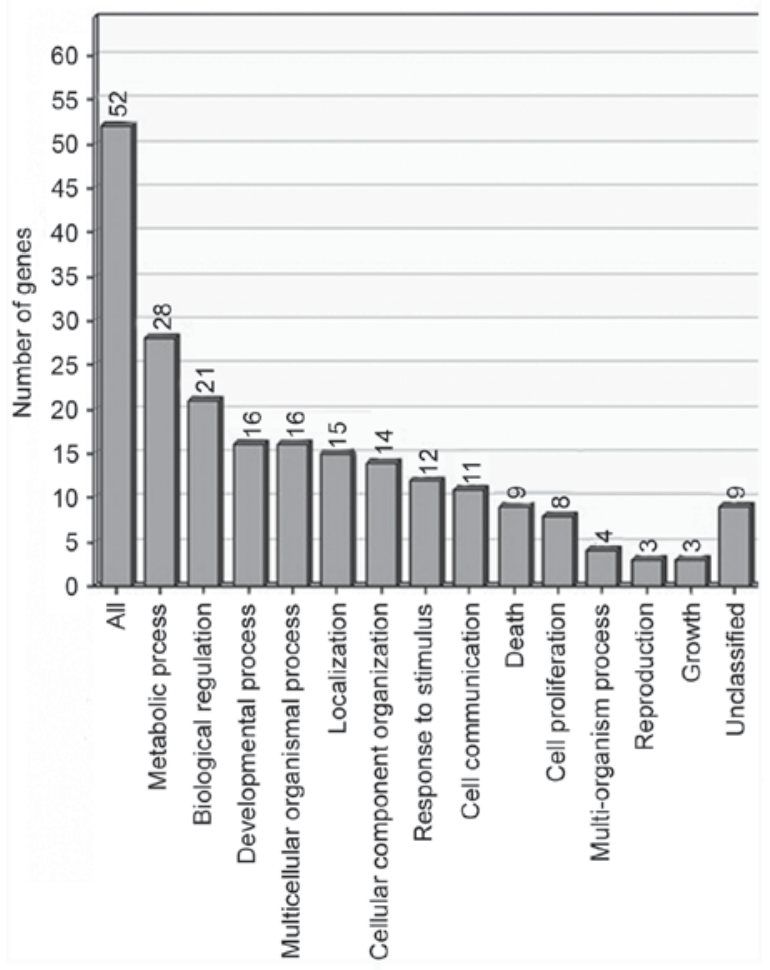

B

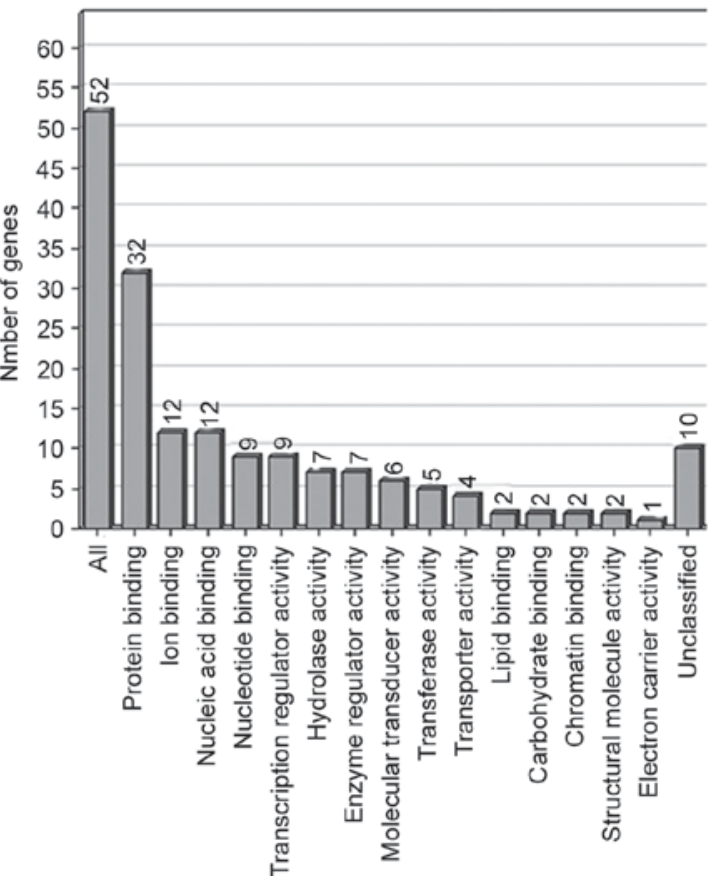

C

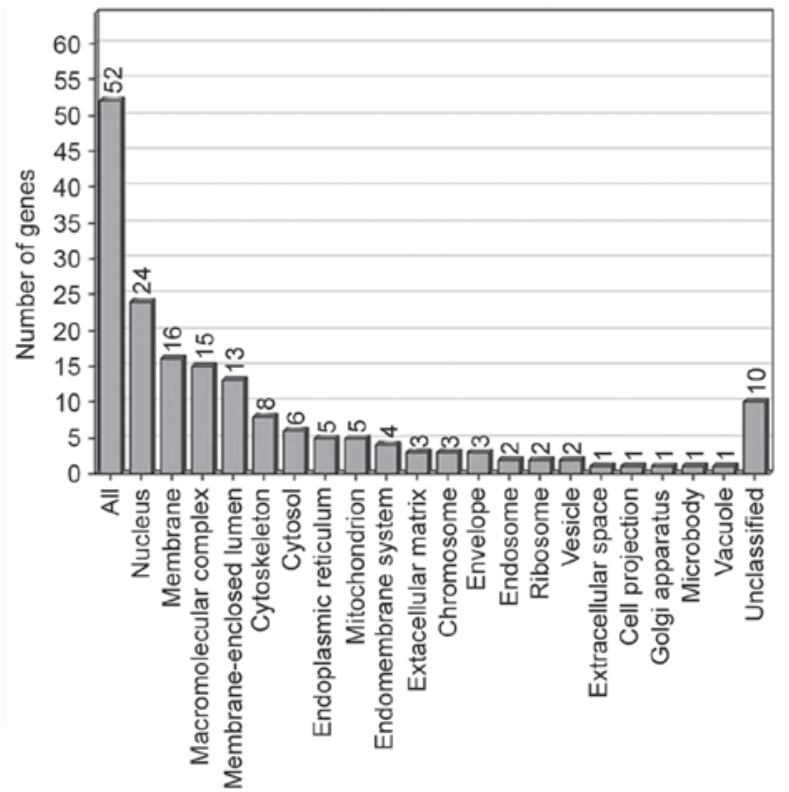

Figure 4. Functional classification of differentially expressed ESTs. (A) Biological process of differentially expressed ESTs. (B) Molecular function of differentially expressed ESTs. (C) Cell component of differentially expressed ESTs. EST, expressed sequence tag.

differentiating and destined to die. The identification of CSCs has marked implications in the study of cancer biology. Previous studies (7-11) have indicated the existence of CSCs in a number of solid tumors and a variety of cell surface makers have been used to isolate CSC subpopulations, including cluster of differentiation (CD)24, CD133 and CD24; however, none of these markers are exclusively expressed by CSCs in solid tumors.

ALDH is a member of the family of $\mathrm{NAD}(\mathrm{P})^{+}$-dependent enzymes involved in detoxifying a variety of aldehydes to the corresponding weak carboxylic acids (23). The use of ALDH activity in flow cytometry-based methods has enabled the isolation of viable CSC subpopulations in a number of cancer types (24-26). In the present study, CSCs were enriched from the tongue squamous cell carcinoma TCA8113 cell line, according to the overexpression of $\mathrm{ALDH}^{\mathrm{br}}$. $\mathrm{ALDH}^{\mathrm{br}}$ cells comprised $1.3 \%$ of the total cell population, which is consistent with previous studies $(13,14)$. Therefore, $\mathrm{ALDH}^{\mathrm{br}}$-associated CSCs were successfully isolated for additional investigation. 
Table III. Pathway analysis, on the basis of the pathway commons database.

\begin{tabular}{|c|c|c|}
\hline Signaling pathway & Entrez IDs & Enrichment statistics \\
\hline Notch-HLH transcription & 1387,4853 & $\mathrm{C}=6 ; \mathrm{O}=2 ; \mathrm{E}=0.01 ; \mathrm{R}=290.63 ; \operatorname{rawP}=1.93 \times 10^{-5} ; \operatorname{adj} \mathrm{P}=0.0004$ \\
\hline TGF- $\beta$ receptor & $1387,5925,960$ & $\mathrm{C}=126 ; \mathrm{O}=3 ; \mathrm{E}=0.14 ; \mathrm{R}=20.76 ; \operatorname{rawP}=0.0004 ; \operatorname{adj} \mathrm{P}=0.0032$ \\
\hline Generic transcription & 1387,4853 & $\mathrm{C}=28 ; \mathrm{O}=2 ; \mathrm{E}=0.03 ; \mathrm{R}=62.28 ; \operatorname{rawP}=0.0005 ; \operatorname{adj} \mathrm{P}=0.0032$ \\
\hline $\begin{array}{l}\text { Microphthalmia-associated } \\
\text { transcription factor }\end{array}$ & 1387,4286 & $\mathrm{C}=51 ; \mathrm{O}=2 ; \mathrm{E}=0.06 ; \mathrm{R}=34.19 ; \operatorname{rawP}=0.0016 ; \operatorname{adj} \mathrm{P}=0.0051$ \\
\hline $\begin{array}{l}\text { Signaling events mediated by } \\
\text { stem cell factor receptor } \\
\text { (c-Kit) }\end{array}$ & $1387,9611,4286,29904$ & $\mathrm{C}=436 ; \mathrm{O}=4 ; \mathrm{E}=0.50 ; \mathrm{R}=8.00 ; \operatorname{rawP}=0.0016 ; \operatorname{adj} \mathrm{P}=0.0051$ \\
\hline BMP receptor & $4086,4286,29904$ & $\mathrm{C}=189 ; \mathrm{O}=3 ; \mathrm{E}=0.22 ; \mathrm{R}=13.84 ; \operatorname{rawP}=0.0014 ; \operatorname{adj} \mathrm{P}=0.0051$ \\
\hline NOTCH & 4853,9611 & $\mathrm{C}=58 ; \mathrm{O}=2 ; \mathrm{E}=0.07 ; \mathrm{R}=30.07 ; \operatorname{rawP}=0.0020 ; \operatorname{adj} \mathrm{P}=0.0054$ \\
\hline $\begin{array}{l}\text { Regulation of cytoplasmic } \\
\text { and nuclear SMAD } 2 / 3\end{array}$ & $9611,4286,29904$ & $\mathrm{C}=265 ; \mathrm{O}=3 ; \mathrm{E}=0.30 ; \mathrm{R}=9.87 ; \operatorname{rawP}=0.0035 ; \operatorname{adj} \mathrm{P}=0.0066$ \\
\hline TGF- $\beta$ receptor & $9611,4286,29904$ & $\mathrm{C}=265 ; \mathrm{O}=3 ; \mathrm{E}=0.30 ; \mathrm{R}=9.87 ; \operatorname{rawP}=0.0035 ; \operatorname{adj} \mathrm{P}=0.0066$ \\
\hline Androgen receptor & 1387,5925 & $\mathrm{C}=79 ; \mathrm{O}=2 ; \mathrm{E}=0.09 ; \mathrm{R}=22.07 ; \operatorname{rawP}=0.0038 ; \operatorname{adj} \mathrm{P}=0.0066$ \\
\hline \multicolumn{3}{|c|}{$\begin{array}{l}\text { Table lists the enriched gene sets, the number of Entrez IDs in the user data set for the pathway, the corresponding Entrez ID and the statistics } \\
\text { for the enrichment of the pathway. The number of user gene IDs is linked to a table with information about the user IDs, and the Entrez IDs } \\
\text { are linked to the Entrez Gene. Notch-HLH, Notch-Helix Loop helix; TGF- } \beta \text {, transforming growth factor- } \beta \text {; BMP, bone morphogenetic protein; } \\
\text { SMAD, mothers against decapentaplegic homolog; C, number of reference genes in the category; O, number of genes in the gene set and in } \\
\text { the category; E, expected number in the category; R, ratio of enrichment; rawP, P-value from the hypergeometric test; adjP, P-value adjusted } \\
\text { by the multiple test adjustment. }\end{array}$} \\
\hline
\end{tabular}

Table IV. Pathway analysis, on the basis of the Wikipathways database.

\begin{tabular}{|c|c|c|}
\hline Signaling pathway & Entrez IDs & Enrichment statistics \\
\hline$\Delta$-Notch & $9611,4853,4086,1956$ & $\mathrm{C}=86 ; \mathrm{O}=4 ; \mathrm{E}=0.10 ; \mathrm{R}=40.55 ; \mathrm{rawP}=3.05 \times 10^{-6} ; \operatorname{adj} \mathrm{P}=3.97 \times 10^{-5}$ \\
\hline Senescence and autophagy & $5925,960,4297$ & $\mathrm{C}=60 ; \mathrm{O}=3 ; \mathrm{E}=0.07 ; \mathrm{R}=43.60 ; \operatorname{rawP}=4.65 \times 10^{-5} ; \operatorname{adj} \mathrm{P}=0.0003$ \\
\hline Androgen receptor & $1387,5925,1956$ & $\mathrm{C}=115 ; \mathrm{O}=3 ; \mathrm{E}=0.13 ; \mathrm{R}=22.75 ; \operatorname{raw} \mathrm{P}=0.0003 ; \operatorname{adj} \mathrm{P}=0.0013$ \\
\hline B cell receptor & $5925,3708,493$ & $\mathrm{C}=158 ; \mathrm{O}=3 ; \mathrm{E}=0.18 ; \mathrm{R}=16.56 ; \operatorname{rawP}=0.0008 ; \operatorname{adj} \mathrm{P}=0.0021$ \\
\hline TGF- $\beta$ receptor & $1387,5925,960$ & $\mathrm{C}=155 ; \mathrm{O}=3 ; \mathrm{E}=0.18 ; \mathrm{R}=16.88 ; \operatorname{rawP}=0.0008 ; \operatorname{adj} \mathrm{P}=0.0021$ \\
\hline Notch & 1387,4853 & $\mathrm{C}=46 ; \mathrm{O}=2 ; \mathrm{E}=0.05 ; \mathrm{R}=37.91 ; \operatorname{rawP}=0.0013 ; \operatorname{adj} \mathrm{P}=0.0026$ \\
\hline Id & 5925,4086 & $\mathrm{C}=51 ; \mathrm{O}=2 ; \mathrm{E}=0.06 ; \mathrm{R}=34.19 ; \operatorname{rawP}=0.0016 ; \operatorname{adj} \mathrm{P}=0.0026$ \\
\hline TGF- $\beta$ & 1387,4086 & $\mathrm{C}=52 ; \mathrm{O}=2 ; \mathrm{E}=0.06 ; \mathrm{R}=33.53 ; \operatorname{raw} \mathrm{P}=0.0016 ; \operatorname{adj} \mathrm{P}=0.0026$ \\
\hline Estrogen & 1387,9611 & $\mathrm{C}=76 ; \mathrm{O}=2 ; \mathrm{E}=0.09 ; \mathrm{R}=22.94 ; \operatorname{raw} \mathrm{P}=0.0035 ; \operatorname{adj} \mathrm{P}=0.0051$ \\
\hline Wnt and pluripotency & 1387,960 & $\mathrm{C}=98 ; \mathrm{O}=2 ; \mathrm{E}=0.11 ; \mathrm{R}=17.79 ; \operatorname{rawP}=0.0057 ; \operatorname{adj} \mathrm{P}=0.0067$ \\
\hline
\end{tabular}

Table lists the enriched gene sets, the number of Entrez IDs in the user data set for the pathway, the corresponding Entrez IDs and the statistics for the enrichment of the pathway. The number of user gene IDs is linked to a table with information about the user IDS and the Entrez IDs are linked to Entrez Gene. Id, the inhibitor of DNA binding; TGF- $\beta$, transforming growth factor- $\beta$; C, number of reference genes in the category; $\mathrm{O}$, number of genes in the gene set and in the category; E, expected number in the category; R, ratio of enrichment; rawP, P-value from the hypergeometric test; adjP, P-value adjusted by the multiple test adjustment.

In order to identify stem cell associated genes differentially expressed in $\mathrm{ALDH}^{\mathrm{br}}$ and $\mathrm{ALDH}^{\text {low }}$ cells, SSH was performed. SSH is advantageous compared with other PCR-based techniques as it selectively amplifies target cDNA fragments (differentially expressed), and simultaneously suppresses non-target DNA amplification, to generate a library of differentially expressed sequences (27). The normalization step equalizes the abundance of cDNAs within a target population and the subtraction step excludes the common sequences between the driver and tester populations (27). In addition, the advantage compared with microarrays is that SSH may isolate novel differentially expressed genes (28). In the present study, two SSH libraries were constructed from cDNAs obtained from $\mathrm{ALDH}^{\mathrm{br}}$ and $\mathrm{ALDH}^{\text {low }}$ cells, and a total of 240 clones were selected and sequenced. Using GenBank databases, 28 and 34 known genes were identified from the forward and reverse libraries, respectively. A total of 28 of clones revealed homology with chromosome sequences and 14 
clones demonstrated homology with ESTs. The known genes were grouped into functional categories on the basis of GO.

In the GO category of biological process, the highly enriched categories included those associated with metabolic processes (28 genes), biological regulation (21 genes) and developmental processes (16 genes). The results of the present study suggested that abnormal stem cell homeostasis associated with the aforementioned processes would result in malignant changes in stem cells.

Signaling pathway analysis identified the 10 pathways that exhibited marked alterations in the Wikipathways database and Pathway Commons database, which included Notch and TGF- $\beta$ signaling pathways, which have been identified to serve important roles in the regulation of stem cell self-renewal, multi-potency and cell-fate determination $(29,30)$. In addition, one gene may participate in different signaling pathways at the same time; for example, the gene encoding cAMP response element-binding protein (CREB) binding protein (CREBBP/CBP) was involved in 7 of the aforementioned signaling pathways and notably interacted with Wnt signaling to maintain the pluriporency of murine embryonic stem cells in long-term culture (31). A previous study demonstrated that CBP was critical in maintaining an adequate pool of murine hematopoietic stem cells through self-renewal and was important for preventing hematological tumor formation (32), suggesting that CBP was associated with the biological regulation of normal stem cells. There have been a limited number of studies on the expression and function of CBP in CSCs, therefore, whether $\mathrm{CBP}$ is a marker of CSCs in tongue squamous cell carcinoma remains unknown. Additionally, nuclear receptor corepressor 1 (NCOR1) was involved in a number of signaling pathways and was initially defined as a regulator of nuclear receptor-mediated repression. NCOR is expressed in the nucleus of neural stem cells (NSCs) and is a regulator of neural stem cells. Following phosphorylation, NCOR translocates to the cytoplasm and induces the astrocytic differentiation of NSCs (33). Furthermore, NCOR has been identified to maintain normal intestinal epithelial cell viability, and silencing of NCOR1 expression in proliferating cells of crypt origin resulted in a rapid viability arrest without associated cell death (34). In glioblastoma multiforme (GBM), NCOR was expressed in the nucleus of undifferentiated CSCs and the nuclear localization of NCOR may function as a marker of GBM stem cells (35).

Differentially expressed genes in tongue squamous carcinoma stem-like cells were profiled using the SSH technique. A total of 62 genes were identified as upregulated or downregulated in tongue squamous carcinoma stem-like cells (termed $\mathrm{ALDH}^{\mathrm{br}}$ cells), suggesting that distinct gene expression profiles are present in CSCs. CBP and NCOR1 genes were involved in a number of signaling pathways in $\mathrm{ALDH}^{\mathrm{br}}$ cells. The results of a literature review suggested that $\mathrm{CBP}$ and NcoR1 may be CSCs markers (32-35), which is consistent with the results of the present study. Although the results of the present study are preliminary, a group of candidate genes have been identified, which require additional study.

\section{Acknowledgements}

The present study was supported by the ChonQing Science and Technology Commission Project (grant no. 2013-1-030). The authors thank Medjaden Bioscience Ltd. (Hong Kong, China) for assisting in the preparation of the original manuscript.

\section{References}

1. Parkin DM, Pisani P and Ferlay J: Global cancer statistics. CA Cancer J Clin 49: 33-64, 1999.

2. Jemal A, Bray F, Center MM, Ferlay J, Ward E and Forman D: Global cancer statistics. CA Cancer J Clin 61: 69-90, 2011.

3. Haddad RI and Shin DM: Resent advances in head and neck cancer. N Engl J Med 359: 1143-1154, 2008.

4. Reya T, Morrison SJ, Clarke MF and Weissman IL: Stem cell, cancer, and cancer stem cell. Nature 414: 105-111, 2001.

5. Pardal R, Clarke MF and Morrison SJ: Applying the principles of stem-cell biology to cancer. Nat Rev Cancer 3: 895-902, 2003.

6. Brabletz T, Jung A, Spaderna S, Hlubek F and Kirchner T: Opinion: Migrating cancer stem cell-an intergrated concept of malignant tumour progression. Nat Rev Cancer 5: 744-749, 2005.

7. Al-Hajj M, Wicha MS, Benito-Hernandez A, Morrison SJ and Clarke MF: Prospective identification of tumorigenic breast cancer cells. Proc Natl Acad Sci USA 100: 3983-3988, 2003.

8. Singh SK, Hawkins C, Clarke ID, Squire JA, Bayani J, Hide T, Henkelman RM, Cusimano MD and Dirks PB: Identification of human brain tumour initiating cells. Nature 432: 396-401, 2004.

9. Ricci-Vitiani L, Lombardi DG, Pilozzi E, Biffoni M, Todaro M, Peschle $C$ and De Maria R: Identification and expansion of human colon-cancer-initiating cells. Nature 445: 111-115, 2007.

10. Schatton T,Murphy GF,FrankNY, Yamaura K, Waaga-Gasser AM, Gasser M, Zhan Q, Jordan S, Duncan LM, Weishaupt C, et al: Identification of cells initiating human melanomas. Nature 451: 345-349, 2008.

11. Pfeiffer MJ and Schalken JA: Stem cell characteristics in prostate cancer cell lines. Eur Urol 57: 246-255, 2010.

12. Clay MR, Tabor M, Owen JH, Carey TE, Bradford CR, Wolf GT, Wicha MS and Prince ME: Single-marker identification of head and neck squamous cell carcinoma cancer stem cells with aldehyde dehydrogenase. Head Neck 32: 1195-1201, 2010.

13. Chen YC, Chen YW, Hsu HS, Tseng LM, Huang PI, Lu KH, Chen DT, Tai LK, Yung MC, Chang SC, et al: Aldehyde dehydrogenase 1 is a putative marker for cancer stem cells in head and neck squamous cancer. Biochem Biophys Res Commun 385: 307-313, 2009.

14. Clay MR, Tabor M, Owen JH, Carey TE, Bradford CR, Wolf GT, Wicha MS and Prince ME: Single-marker identification of head and neck squamous cell carcinoma cancer stem cells with aldehyde dehydrogenase. Head Neck 32: 1195-1201, 2010.

15. Galli R, Binda E, Orfanelli U, Cipelletti B, Gritti A, De Vitis S, Fiocco R, Foroni C, Dimeco F and Vescovi A: Isolation and characterization of tumorigenic, stem-like neural precursors from human glioblastoma. Cancer Res 64: 7011-7021, 2004

16. Yuan X, Curtin J, Xiong Y, Liu G, Waschsmann-Hogiu S, Farkas DL, Black KL and Yu JS: Isolation of cancer stem cells from adult glioblastoma multiforme. Oncogene 23: 9392-9400, 2004.

17. Mahalingam R, Gomez-Buitrago A, Eckardt N, Shah N, GuevaraGarcia A, Day P, Raina R and Fedoroff NV: Characterizing the stress/defense transcriptome of Arabidopsis. Genome Biol 4: R20, 2003.

18. Hemmati HD, Nakano I, Lazareff JA, Masterman-Smith M, Geschwind DH, Bronner-Fraser M and Kornblum HI: Cancerous stem cells can arise from pediatric brain tumors. Proc Natl Acad Sci USA 100: 15178-15183, 2003

19. Fang D, Nguyen TK, Leishear K, Finko R, Kulp AN, Hotz S, Van Belle PA, Xu X, Elder DE and Herlyn M: A tumorigenic subpopulation with stem cell properties in melanomas. Cancer Res 65: 9328-9337, 2005.

20. Vermeulen L, Todaro M, de Sousa Mello F, Sprick MR, Kemper K, Perez Alea M, Richel DJ, Stassi G and Medema JP: Single-cell cloning of colon cancer stem cells reveals a multi-lineage differentiation capacity. Proc Natl Acad Sci USA 105: 13427-13432, 2008

21. Clarke MF, Dick JE, Dirks PB, Eaves CJ, Jamieson CH, Jones DL, Visvader J, Weissman IL and Wahl GM: Cancer stem cells-perstectives on current status and future directions: AACR Workshop on cancer stem cells. Cancer Res 66: 9339-9344, 2006.

22. Bommet D and Dick JE: Human acute myeloid leukemia is organized as a hierarchy that originates from a primitive hematopoietic cell. Nat Med 3: 730-737, 1997. 
23. Sládek NE: Human aldehyde dehydrogenases: Potential pathological, pharmacological, and toxicological impact. J Biochem Mol Toxicol 17: 7-23, 2003.

24. Ginestier C, Hur MH, Charafe-Jauffret E, Monville F, Dutcher J, Brown M, Jacquemier J, Viens P, Kleer CG, Liu S, et al: ALDH1 is a marker of normal and malignant human mammary stem cells and a predictor of poor clinical outcome. Cell Stem Cell 1: 555-567, 2007.

25. Chu P, Clanton DJ, Snipas TS, Lee J, Mitchell E, Nguyen ML, Hare E and Peach RJ: Characterization of a subpopulation of colon cancer cells with stem cell-like properties. Int J Cancer 124: 1312-1321, 2009

26. van den Hoogen C, van der Horst G, Cheung H, Buijs JT, Lippitt JM, Guzmán-Ramírez N, Hamdy FC, Eaton CL, Thalmann GN, Cecchini MG, et al: High aldehyde dehydrogenase activity identifies tumor-initiating and metastasis-initiating cells in human prostate cancer. Cancer Res 70: 5163-5173, 2010.

27. Hillmann A, Dunne E and Kenny D: cDNA amplification by SMART-PCR and suppression subtractive hybridization (SSH)-PCR. Methods Mol Biol 496: 223-243, 2009.

28. Niu L, Mantri N, Li CG, Xue C and Pang E: Array-based techniques for fingerprinting medicinal herbs. Chin Med 6: 18, 2011.

29. Wang Z, Li Y, Banerjee S and Sarkar FH: Emerging role of Notch in stem cells and cancer. Cancer Lett 279: 8-12, 2009.

30. Mendelson J, Song S, Li Y, Maru DM, Mishra B, Davila M, Hofstetter WL and Mishra L: Dysfunctional transforming growth factor- $\beta$ signaling with constitutively active notch signaling in Barrett's esophageal Adenocarcinoma. Cancer 117: 3691-3702, 2011.
31. Miyabayashi T, Teo JL, Yamamoto M, McMillan M, Nguyen C and Kahn M: Wnt/beta-catenin/CBP signaling maintains long-term murine embryonic stem cell pluripotency. Proc Natl Acad Sci USA 104: 5668-5673, 2007.

32. Rebel VI, Kung AL, Tanner EA, Yang H, Bronson RT and Livingston DM: Distinct roles for CREB-binding protein and p300 in hematopoietic stem cell self-renewal. Proc Natl Acad Sci USA 99: 14789-14794, 2002.

33. Hermanson O, Jepsen K and Rosenfeld MG: N-CoR controls differentiation of neural stem cells into astrocytes. Nature 419: 934-939, 2002.

34. Doyon G, St-Jean S, Darsigny M, Asselin C and Boudreau F: Nuclear receptor co-repressor is required to maintain proliferation of normal intestinal epithelial cells in culture and down-modulates the expression of pigment epithelium derived factor. J Biol Chem 284: 25220-25229, 2009.

35. Park DM, Li J, Okamoto H, Akeju O, Kim SH, Lubensky I, Vortmeyer A, Dambrosia J, Weil RJ, Oldfield EH, et al: N-CoR pathway tatgeting induces glioblastoma derived cancer stem cell differentiation. Cell Cycle 6: 467-470, 2007. 